Li, C., P. Cui, S. Zhou, and S. Yang. 2018. How do farmland bird communities in rural settlements respond to human relocations associated with land subsidence induced by coal mining in China? Avian Conservation and Ecology 13(1):6. https://doi.org/10.5751/ACE-01164-130106

Copyright (C) 2018 by the author(s). Published here under license by the Resilience Alliance.

Research Paper

\title{
How do farmland bird communities in rural settlements respond to human relocations associated with land subsidence induced by coal mining in China?
}

\author{
Chunlin $\mathrm{Li}^{1}$, Peng $\mathrm{Cui}^{2}$, Sheng Zhou ${ }^{1}$ and Sen Yang ${ }^{1}$ \\ ${ }^{1}$ School of Resources and Environmental Engineering, Anhui University, ${ }^{2}$ Nanjing Institute of Environmental Sciences, Ministry of \\ Environmental Protection
}

\begin{abstract}
Large-scale underground coal mining has created large-area land subsidence in the North China Plain, resulting in drastic habitat changes for farmland birds. Among others, relocation of local residents due to land subsidence may lead to a reduction in human disturbance, and accompanying vegetation recovery in rural settlements. However, it remains largely unknown how farmland birds respond to these environmental changes. During the summer of 2016 and winter of 2016-2017, we used the line transect method to quantify farmland bird communities in both inhabited and recently abandoned villages in the Huaibei coal mining area in the North China Plain. We hypothesized that bird communities would change in terms of abundance, species diversity, and composition as a response to human relocations. We also explored relative effects of reductions in human disturbance, and accompanying changes in vegetation. Both cover and vertical diversity of vegetation increased following relocations of local residents in abandoned villages. Bird abundance, species richness, and diversity were higher in these villages in both summer and winter. Bird species composition also differed between the two village types in both summer and winter. Compositional differences in bird communities were related to both human disturbance and vegetation structure, but more to the latter. Farmland birds positively responded to lower human disturbance, even though they are well-adapted to the disturbed agricultural environment. However, these temporarily positive effects may disappear in the near future, given the upcoming transition from terrestrial ecosystem into subsidence ponds because of continuing underground coal mining. We should further monitor changes in bird communities, and effects of coal mining at a regional scale, rather than being too optimistic on temporarily positive effects of local disturbance reduction. We provide a small-scale but important case study that may prompt urgent attention to farmland bird communities in large-scale agricultural landscapes in China.
\end{abstract}

\section{De quelle façon les communautés d'oiseaux champêtres en milieu rural réagissent-elles aux relocalisations des résidents consécutives aux affaissements du sol causés par l'extraction du charbon en Chine?}

RÉSUMÉ. Les mines de charbon sous-terraines à grande échelle ont provoqué de vastes affaissements du sol dans la plaine du nord de la Chine, entraînant des changements d'habitat radicaux pour les oiseaux champêtres. Entre autres, la relocalisation des résidents locaux consécutive aux affaissements pourrait amener une réduction du dérangement humain et le rétablissement de la végétation dans les villages ruraux. Toutefois, on en connait encore très peu sur le comportement des oiseaux champêtres face à ces changements environnementaux. Durant l'été 2016 et l'hiver 2016-2017, nous avons quantifié les communautés d'oiseaux champêtres dans les villages habités et les villages récemment abandonnés dans la région minière de Huaibei, dans la plaine du nord de la Chine, au moyen de la méthode des transects. Nous avons supposé que les communautés d'oiseaux changeraient sur le plan de l'abondance, de la diversité et de la composition d'espèces à la suite de la relocalisation des résidents. Nous avons aussi exploré les effets relatifs de la réduction du dérangement humain et les changements en parallèle de la végétation. Tant la couverture que la diversité verticale de la végétation ont augmenté à la suite de la relocalisation des résidents dans les villages abandonnés. L'abondance, la richesse et la diversité spécifique aviaire étaient plus élevées dans ces villages, en été comme en hiver. La composition spécifique aviaire différait aussi entre les deux types de villages en été et en hiver. Les différences dans la composition des communautés aviaires étaient liées au dérangement humain, mais encore plus à la structure de la végétation. Les oiseaux champêtres ont réagi positivement au dérangement humain moins élevé, même s'ils sont pourtant bien adaptés à un environnement agricole perturbé. Cependant, ces effets pour l'instant positifs disparaîtront peutêtre dans un proche avenir, puisqu'on anticipe une transition de l'écosystème terrestre vers des étangs créés par les affaissements sachant que l'activité minière sous-terraine pour l'extraction du charbon se poursuit. Nous devrions accorder plus d'attention aux changements des communautés aviaires et aux effets de l'extraction du charbon à l'échelle régionale, plutôt que de trop se réjouir des effets positifs temporaires de la réduction locale du dérangement. Nous présentons une étude de cas à petite échelle mais importante, qui révèle une certaine urgence de porter attention aux communautés d'oiseaux champêtres dans les vastes étendues de paysages agricoles en Chine.

Key Words: habitat changes; human disturbance; species diversity; vegetation structure

Address of Correspondent: Sen Yang, School of Resources and Environmental Engineering, Anhui University, No.111, Jiulong Road, 230601, Hefei, China, 1356593094@qq.com 


\section{INTRODUCTION}

Rural settlements in agricultural landscapes across the world can provide important habitats for farmland biodiversity (Hiron et al. 2013, Rosin et al. 2016). Because of a lack of conservation efforts, however, marked negative trends in farmland biodiversity have been recorded worldwide, caused by agricultural intensification, landscape homogenization, and habitat losses (Herzon et al. 2008, Strohbach et al. 2015). Among affected faunal communities, birds are one of the most sensitive taxa to habitat changes (Shahabuddin and Kumar 2006, Rosin et al. 2016). Therefore, birds are often used as indicators to quantify environmental changes (Padoa-Schioppa et al. 2006).

The relationship between birds and habitats has been comprehensively studied along gradients of many environmental factors at various spatial scales (Watson et al. 2005, Gaüzère et al. 2015, Zlonis et al. 2017). Among others, human disturbance and vegetation structure are two well-studied factors that may have mixed effects on bird communities. Bird species diversity is positively related to both cover and vertical diversity of vegetation (MacArthur and MacArthur 1961, Francl and Schnell 2002, Kirk et al. 2012). Human disturbance can directly drive bird population declines by increasing mortality rates, and affecting habitat use of birds (Hockin et al. 1992, Zhang et al. 2017a). Bird communities can also be indirectly influenced by human disturbance via accompanying changes in vegetation structure (Shahabuddin and Kumar 2006). A large number of studies have reported declines of bird abundance and species diversity caused by increasing human disturbance and human-induced vegetation deterioration (Francl and Schnell 2002, Thiollay 2006, Schütz and Schulze 2015). However, it remains largely unknown how human relocations affect farmland birds, which are well-adapted to intensive disturbance in highly populated rural settlements.

As a large agricultural country, China's farmlands occupy an area of $1,350,000 \mathrm{~km}^{2}$, and are mainly distributed in plains and basins in northern and eastern regions (Kong 2014). These arable lands not only provide food for 1.4 billion people, but also provide habitats for diverse farmland birds (Liu et al. 2013). In agricultural landscapes, rural settlements are increasingly identified as important spots for farmland birds (Hiron et al. 2013, Rosin et al. 2016). Compared to homogeneous croplands, plant communities in rural settlements provide birds with more diverse microhabitats for nesting and foraging (Ahnström et al. 2008, Strohbach et al. 2015). However, along with rural development and the increasing intensification of agriculture, habitats for farmland birds have undergone drastic changes during the last few decades in China. In developing countries such as China, limited resources are focused on biodiversity conservation in established protected areas such as nature reserves and national parks, rather than in agricultural landscapes (Xu et al. 2017, Zhang et al. 2017b). Therefore, the effects of these changes on farmland bird communities remain largely unknown in China (Liu et al. 2013).

More than $40 \%$ of farmlands in China overlap with coal resources, and by 2011, land subsidence caused by underground coal mining affected areas totaling $10,000 \mathrm{~km}^{2}$, with an annual expansion of $700 \mathrm{~km}^{2}$ (Hu et al. 2014). This large-scale land subsidence has led to many challenging ecological and socioeconomic problems, and it has impacted the livelihood of affected people, as well as regional biodiversity (Xie et al. 2013, Dong et al. 2015). Because of abundant rainfall and high underground water levels, the subsiding land surfaces in the North China Plain gradually change into wetlands within a few years. Local residents in villages located in subsiding areas are relocated before land subsidence (Hu et al. 2014, Xiao et al. 2017). As a result, human activities and their potential effects on local flora and fauna communities will be reduced significantly. This creates an opportunity for us to investigate how farmland birds respond to habitat changes in these rural settlements, and thus further our understanding of anthropogenic impacts on vegetation and bird communities.

We investigated how farmland bird communities respond to human relocations associated with land subsidence induced by coal mining in the agricultural landscape of the North China Plain. We quantified farmland bird community structures in both inhabited and abandoned villages, and hypothesized that bird communities would change in response to relocations of local residents. Specifically, we tested expectations that (1) bird abundance, species richness and diversity should increase in abandoned villages, and (2) bird species composition should differ between the two types of villages. Relative effects of reduction in human disturbance and accompanying changes in vegetation structure were explored. We also discuss potential effects of the upcoming transition from terrestrial ecosystem into subsidence wetlands on farmland birds in these subsiding areas.

\section{METHODS}

\section{Study area}

The study was conducted in the Huaibei coal mining area located in the southern part of the North China Plain (in Suixi County, Anhui Province, $32^{\circ} 44^{\prime}-33^{\circ} 44^{\prime} \mathrm{N}, 116^{\circ} 02^{\prime}-117^{\circ} 31^{\prime} \mathrm{E}$; Fig. 1). The region has a typical warm, temperate, semihumid, monsoon climate, with an average annual temperature of $14.7^{\circ} \mathrm{C}$. The average annual precipitation is $933 \mathrm{~mm}$, with most falling from April to August.

The Huaibei Plain is an important area for farming commodity grains in China, and it supports a dense population living in island-like rural settlements scattered across the agricultural landscape. The plain is also an important coal basin in China, encompassing an area of $18,000 \mathrm{~km}^{2}$ (Liu et al. 2009 , Hu et al. 2014). Large-scale coal mining has resulted in extensive ground deformation and subsidence in this region. By 2010, the subsidence area had exceeded $300 \mathrm{~km}^{2}$, with an annual expansion of more than $20 \mathrm{~km}^{2}$ (Xie et al. 2013). Because of land subsidence caused by coal mining, local residents in many subsiding villages have been relocated to safe places (Hu et al. 2014, Xiao et al. 2017). Usually, abandoned, subsiding villages were left as is after human relocations, and they would be covered by water a few years after they were abandoned, depending on the speed of underground coal mining.

We identified in this study "inhabited villages" as rural settlements where no human relocations had occurred, and "abandoned villages" as those where most local residents had been relocated as a response to land subsidence. Because most land subsidence occurred in croplands, and many villages in subsiding areas had been covered by water, we could only find six abandoned villages where terrestrial ecosystems had not been replaced by wetlands, 
Fig. 1. Map of surveyed villages in the Huaibei coal mining area located in the southern part of the North China Plain.

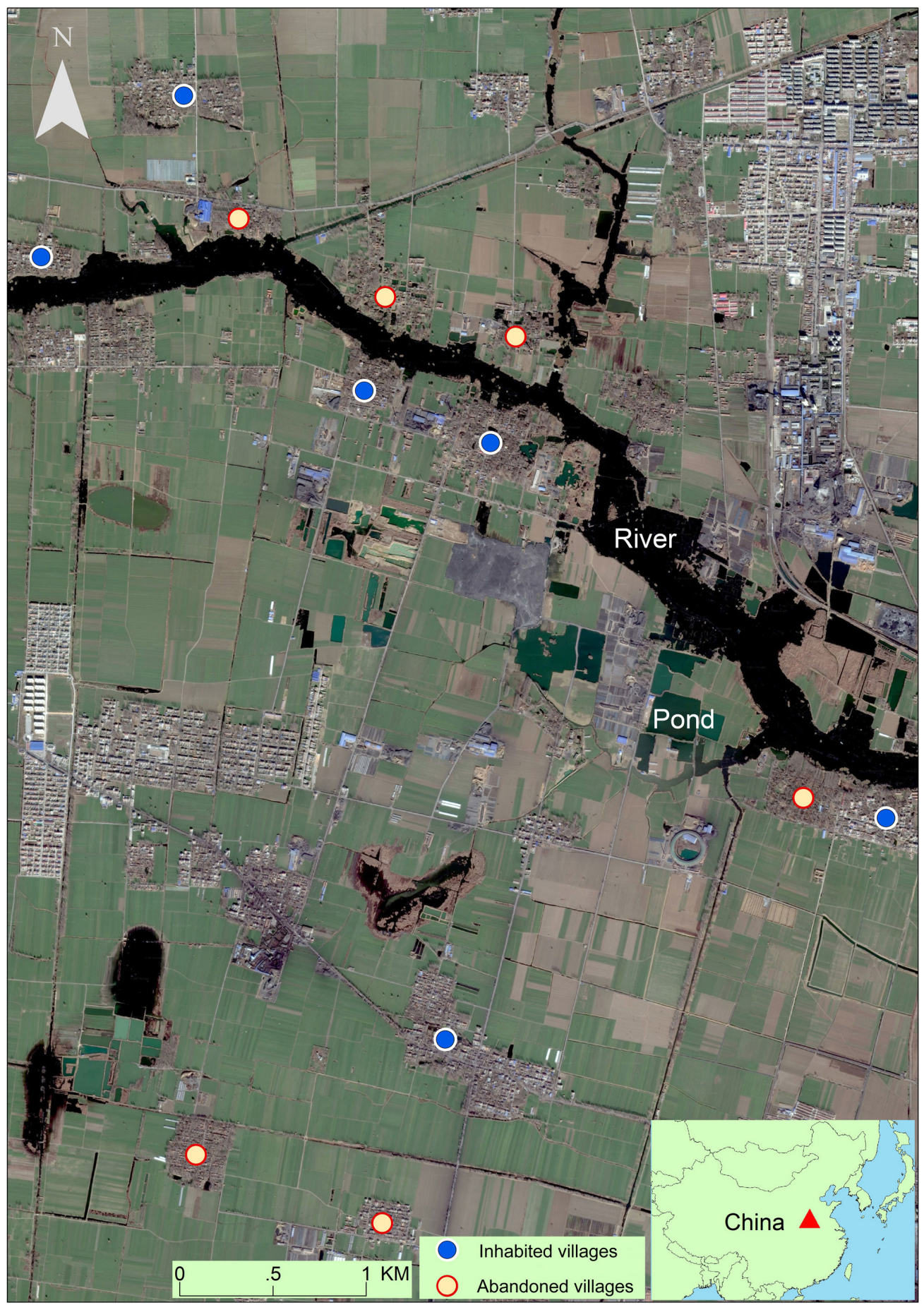

and that were large enough for locating one 500-m line transect. Relocation efforts in these villages ended in different years from 2011 to 2016, and only a small number of households remained in the abandoned villages. As required for a balanced design, we randomly selected six inhabited villages as controls. We used the number of households present in both types of villages as the index of human disturbance in relation to birds. Our limited number of sampled villages is a representative sample of abandoned and inhabited villages in this region, as the rural environment was rather homogeneous across the region. 


\section{Bird counts}

We used the line transect method for collecting data on bird diversity and abundance (Gregory et al. 2004). Because of the relatively small area available (see below), one 500-m fixed line transect (30 $\mathrm{m}$ on either side) was conducted in each village, passing through various land-covers. We sampled these transects five times on sunny days without strong wind in August 2016 and February 2017, respectively. As such, a total of 120 transect counts were carried out during field surveys. The order of villages surveyed was rotated on different days. We started bird counts half an hour after sunrise and continued for two or three hours, i.e., 06:00 09:00 in summer, and 07:00 09:30 in winter. During field surveys, the observer travelled at a speed of approximately $2 \mathrm{~km} / \mathrm{h}$, and recorded all birds occurring within transect boundaries. Calling or singing birds were also recorded if the observer could confirm that they were within the observation area. Birds that flew over the survey area, except those flushed out from within the observation belt, were not included. We did not perform distance sampling because our transects were relatively narrow, and birds were conspicuous and active during our surveys, allowing good detections. We assumed that detection probabilities were consistent between transects because the same observer (S. Y.) conducted all the bird counts during both seasons. We acknowledge however, that a few individuals may have remained undetected. However, our goal was to test the effect of human relocation on bird community structures rather than to know the absolute bird density in each habitat. Therefore, we used direct bird count data, without correcting for detectability, in subsequent analyses. We determined bird species richness in each village as the total number of species identified over five surveys in each season. Bird abundance, species diversity (ShannonWiener index), and evenness (Pielou's index) were calculated for each survey in a village (Shannon and Weaver 1949, Pielou 1966), and were then averaged over five temporal replicates in each season to be used in following analyses.

\section{Vegetation structure}

Vegetation data were collected during field surveys in August 2016. No significant changes in vegetation structure, except that induced by plant phenology, had occurred in surveyed villages during the study period. We randomly placed six $10 \times 10 \mathrm{~m}$ quadrats within the observation area along each line transect used for bird counting. All plant species in a given quadrat were identified and grouped into three layers, i.e., tree, shrub, and herbaceous grass. For convenience, we defined trees as woody plants with height $>3 \mathrm{~m}$ and girth at breast height $(\mathrm{GBH})>20$ $\mathrm{cm}$, shrubs as those with heights $>1 \mathrm{~m}$ and $\mathrm{GBH}<20 \mathrm{~cm}$, and herbaceous grasses as annual or perennial grasses. In each quadrat, we recorded the number of vegetation layers, number of trees, cover of trees ( $\%)$, shrubs (\%), and herbaceous grasses $(\%)$. We also determined the area of each village and the percent of vegetated area (\%), using the Google Earth imagery of high spatial resolution.

\section{Data analysis}

Prior to statistical analyses, data were systematically tested for normality using the Shapiro-Wilk test. We used the nonparametric Kruskal-Wallis tests to compare vegetation structure attributes between abandoned and inhabited villages. We performed a principal components analysis (PCA) to summarize highly correlated vegetation variables into two independent principal components (PC1 and PC2) that could explain most of the original variance.

A two-way ANOVA was used to explore effects of season, village type, and their interaction with species richness, bird abundance, and Shannon-Wiener indices, which were normally distributed. Friedman $\mathrm{M}$ test was used to compare the difference in the nonnormally distributed Pielou's index between seasons and village types. We used $t$-tests to compare the abundance of each bird species between the two village types. We performed indicator species analysis to explore the specificity and fidelity of each species to village types using an indicator value (IndVal; De Cáceres and Legendre 2009). The method assesses association strength of a species to a given habitat based on a randomization procedure (999 iterations in this study).

The multiresponse permutation procedure (MRPP) was used to test the difference in bird species composition between abandoned and inhabited villages. Using the bird species-site matrix, the MRPP provides a test of whether there are significant differences in species composition among two or more groups of sampling units. Based on randomizations (999 iterations in this study), the MRPP compares the within-group compositional dissimilarity with that between random collections of sampling units from the entire population. To assess bird species compositional similarities between villages, we used the Sørensen's similarity index, in which species abundance rather than presence-absence data is used (McCune and Grace 2002).

We used Mantel's test to determine whether vegetation characteristics could account for the species compositional difference between abandoned and inhabited villages. First, a similarity matrix of bird species composition between villages for each season was calculated using the Bray-Curtis similarity index, as recommended by Krebs (1999). Second, we calculated a similarity matrix of vegetation structure for villages based on their distributions in the PC1-PC2 space. Then, Mantel's test was used to calculate the simple correlation coefficient between these two matrices and test significance of the association based on randomization procedures (999 iterations, in this study) (McCune and Grace 2002). We also used partial Mantel's test to explore the association between bird species composition and vegetation structure while controlling for effects of human disturbance and village areas, respectively.

All statistical analyses were performed with $\mathrm{R}$ version 3.3 .1 ( $\mathrm{R}$ Development Core Team 2017), using the package vegan version 2.4.3 (Oksanen et al. 2017) for the MRPP and Mantel's test, and the package indicspecies version 1.7.6 (De Caceres and Jansen 2016) for the IndVal analysis. Statistical significance was set as $P$ $<0.05$. Data are shown as mean $\pm \mathrm{SE}$.

\section{RESULTS}

There were no differences $\left(\chi^{2}=0.92, P=0.337\right)$ in area sizes between abandoned (11.5 $\pm 1.7 \mathrm{ha})$ and inhabited villages (15.5 \pm 3.7 ha). There were many more households in inhabited villages $(179.7 \pm 52.4)$, than in abandoned villages $\left(5.8 \pm 2.4 ; \chi^{2}=8.46, \mathrm{P}\right.$ $=0.004)$. Compared with inhabited villages, vegetation cover was higher in abandoned villages with more vegetation layers and more cover of shrubs and herbaceous grasses. No difference was found in the number and cover of trees between the two types of 
Table 1. Differences in vegetation variables between abandoned and inhabited villages in the Huaibei coal mining area in the North China Plain.

\begin{tabular}{|c|c|c|c|}
\hline & Abandoned villages & $\begin{array}{c}\text { Inhabited } \\
\text { villages }\end{array}$ & $\begin{array}{l}\text { Significance of } \\
\text { differences }\end{array}$ \\
\hline Percentage of vegetated area $(\%)$ & $69.8 \pm 6.6$ & $32.5 \pm 5.3$ & $\chi^{2}=7.41, P=0.006$ \\
\hline Number of vegetation layers & $2.5 \pm 0.1$ & $1.7 \pm 0.1$ & $\chi^{2}=8.40, P=0.004$ \\
\hline Number of trees & $5.7 \pm 1.0$ & $6.3 \pm 0.9$ & $\chi^{2}=0.10, P=0.748$ \\
\hline Cover of trees $(\%)$ & $55.8 \pm 6.1$ & $52.4 \pm 6.5$ & $\chi^{2}=0.32, P=0.575$ \\
\hline Cover of shrubs $(\%)$ & $46.0 \pm 6.2$ & $11.1 \pm 4.2$ & $\chi^{2}=5.81, P=0.016$ \\
\hline Cover of herbaceous grasses $(\%)$ & $71.1 \pm 5.1$ & $37.2 \pm 7.0$ & $\chi^{2}=6.68, P=0.010$ \\
\hline
\end{tabular}

villages (Table 1). The two principal components (PCA) accounted for $77.2 \%$ of the total variance of vegetation variables (Table 2). Abandoned and inhabited villages could be easily separated by PC1 in the PC1-PC2 space (Fig. 2).

Table 2. Results of the principal components analysis of vegetation variables in rural settlements in the Huaibei coal mining area in the North China Plain. PC = principal components.

\begin{tabular}{lcc}
\hline \hline & PC1 & PC2 \\
\hline Percentage of vegetated area & -0.504 & -0.103 \\
Number of vegetation layers & -0.506 & -0.273 \\
Number of trees & 0.216 & -0.637 \\
Cover of trees & 0.138 & -0.698 \\
Cover of shrubs & -0.480 & -0.137 \\
Cover of herbaceous grasses & -0.441 & -0.743 \\
Eigenvalues & 1.72 & 1.30 \\
Variance explained (\%) & 49.1 & 28.1 \\
Cumulative variance (\%) & 49.1 & 77.2 \\
\hline
\end{tabular}

Fig. 2. Distribution of surveyed sites (V1-V6: abandoned villages; V7-V12: inhabited villages) in the PC1-PC2 space produced by the principal components analysis of vegetation variables.

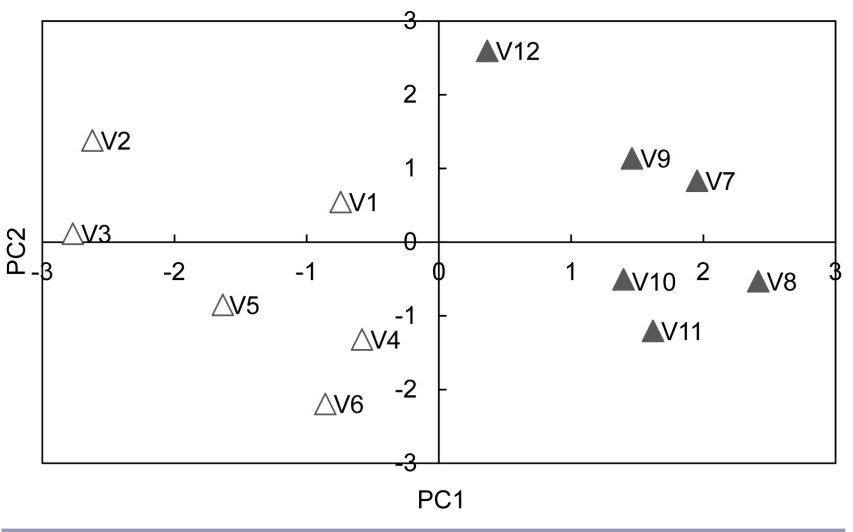

During field surveys, we recorded 9279 birds, belonging to 47 species and 26 families (Appendix 1). We found more bird species $\left(\mathrm{F}_{1,20}=84.83, \mathrm{P}<0.001\right)$ in abandoned villages (45 in total, 30 in summer and 34 in winter) than in inhabited villages ( 25 in total, 19 in summer and 18 in winter). There was no effect of season on the bird species richness $\left(\mathrm{F}_{1,20}=1.57, \mathrm{P}=0.225\right)$. The significant interaction between season and village type $\left(\mathrm{F}_{1,20}=6.65, \mathrm{P}=\right.$ 0.018 ) indicated that more bird species were recorded in winter than in summer for abandoned villages, but no effect of season existed for inhabited villages. The number of birds in abandoned villages was nearly twice that found in inhabited villages $\left(\mathrm{F}_{1,20}=\right.$ $29.29, \mathrm{P}<0.001)$. There were more birds recorded in winter than in summer $\left(F_{1,20}=10.11, P=0.005\right)$. Shannon-Wiener species diversity indices were higher in abandoned villages than those in inhabited villages $\left(\mathrm{F}_{1,20}=36.75, \mathrm{P}<0.001\right)$. Species diversity did not differ between seasons $\left(F_{1,20}=0.76, P=0.393\right)$. No difference in Pielou's evenness indices was found between seasons or between village types $\left(\chi^{2}=2.0, P=0.157\right.$; Fig. 3$)$.

Fig. 3. Differences in bird counts and community indices between seasons and village types in the Huaibei coal mining area of the North China Plain.

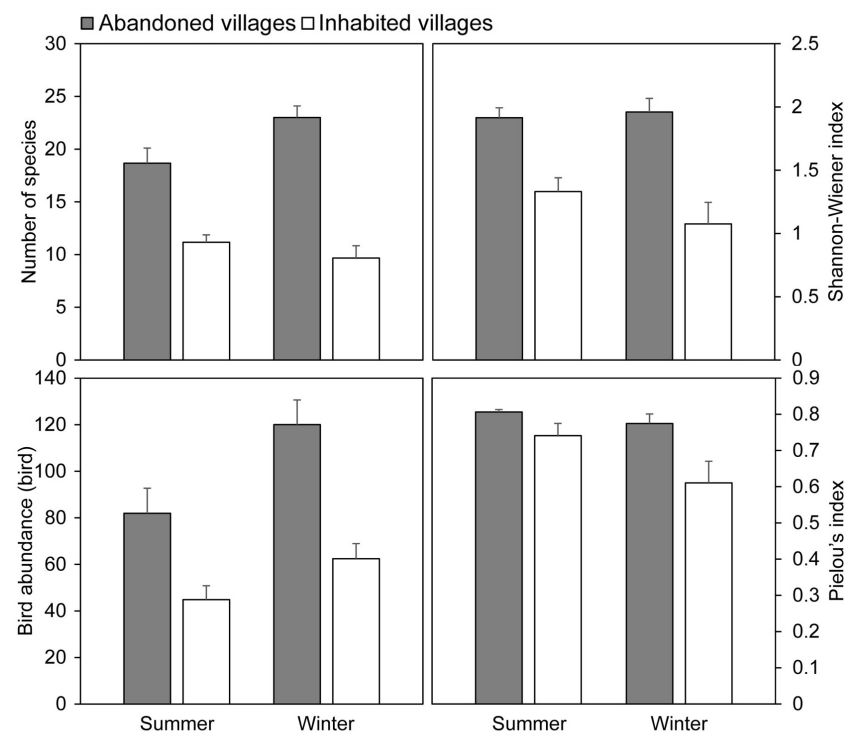

In summer, 13 species were recorded only in abandoned villages, but two species were recorded only in inhabited villages. In winter, 16 species were specific to the former habitat type, but none to the latter. There were six species in summer, and nine in winter that were more abundant in abandoned villages. Only one species (Eurasian Tree Sparrow, Passer montanus) was more abundant in inhabited villages (Appendix 1). The IndVal analysis revealed that 
Table 3. Results of indicator species analysis (De Cáceres and Legendre 2009), showing that three species in summer and eight in winter were significantly associated to abandoned villages in the Huaibei coal mining area in the North China Plain. The indicator value (IndVal) represents the degree to which a given species is associated with the habitats. No significant associations were found in inhabited villages in either season.

\begin{tabular}{|c|c|c|c|c|c|}
\hline Season & Family & Common name & Scientific name & IndVal & $P$ value \\
\hline \multirow[t]{3}{*}{ Summer } & Laniidae & Long-tailed Shrike & Lanius schach & 0.933 & 0.025 \\
\hline & Accipitridae & Common Hoopoe & Upupa epops & 0.894 & 0.045 \\
\hline & Motacillidae & White Wagtail & Motacilla alba & 0.884 & 0.035 \\
\hline \multirow[t]{8}{*}{ Winter } & Phasianidae & Ring-necked Pheasant & Phasianus colchicus & 1.000 & 0.010 \\
\hline & Corvidae & Black-billed Magpie & Pica hudsonia & 0.950 & 0.020 \\
\hline & Aegithalidae & Northern Long-tailed Tit & Aegithalos caudatus & 0.942 & 0.010 \\
\hline & Columbidae & Eastern Spotted Dove & Spilopelia chinensis & 0.928 & 0.025 \\
\hline & Emberizidae & Yellow-throated Bunting & Emberiza elegans & 0.913 & 0.020 \\
\hline & Fringillidae & Grey-capped Greenfinch & Chloris sinica & 0.913 & 0.020 \\
\hline & Fringillidae & Brambling & Fringilla montifringilla & 0.913 & 0.020 \\
\hline & Laniidae & Long-tailed Shrike & Lanius schach & 0.876 & 0.050 \\
\hline
\end{tabular}

three species in summer and eight in winter were associated with abandoned villages. There were no species associated with inhabited villages either in summer or winter (Table 3).

MRPP indicated that there were differences in bird species composition between abandoned and inhabited villages in both summer $(\mathrm{P}=0.003)$ and winter $(\mathrm{P}=0.005)$. The species compositional difference in bird communities between villages was correlated positively with the dissimilarity in vegetation characteristics in both summer $\left(\mathrm{r}_{\mathrm{M}}=0.594, \mathrm{P}=0.001\right)$ and winter $\left(r_{M}=0.632, P=0.002\right)$. The partial Mantel's test revealed that the association between bird species composition and vegetation structure held true while accounting for the effect of human disturbance in both summer $\left(\mathrm{r}_{\mathrm{M}}=0.557, \mathrm{P}=0.001\right)$ and winter $\left(r_{M}=0.599, P=0.001\right)$. Human disturbance also affected bird species composition when vegetation structure was taken into account (summer: $r_{M}=0.392, P=0.003$, winter: $r_{M}=0.307, P=$ $0.009)$. While controlling for the effect of village areas, bird species composition was related to the vegetation structure both in $\operatorname{summer}\left(\mathrm{r}_{\mathrm{M}}=0.600, \mathrm{P}=0.001\right)$ and winter $\left(\mathrm{r}_{\mathrm{M}}=0.633, \mathrm{P}=0.001\right)$. However, there was no effect of village areas on bird communities when accounting for the effect of vegetation structure (summer: $r_{M}=0.119, P=0.181$, winter: $r_{M}=0.054, P=0.280$ ).

\section{DISCUSSION}

Our study revealed that removal of human disturbance ultimately resulted in an increase in bird abundance and species diversity in rural settlements in the agricultural landscape of the North China Plain. Bird species composition also differed significantly between abandoned and inhabited villages. Human disturbance can influence bird communities directly (Hockin et al. 1992, Murphy and Romanuk 2014), or indirectly via modifying vegetation structure at multispatial scales (Shahabuddin and Kumar 2006, Fischer et al. 2011). The accompanying modification of vegetation structure is often suggested as the most important driving factor that impacts bird communities (Skowno and Bond 2003, Shahabuddin and Kumar 2006). Cover of vegetation, as well as the number of vegetation layers, increased following the relocation of local residents in abandoned villages, providing farmland birds with more microhabitats to forage and nest. Some studies of the relationship between birds and habitats found little additional effects of human disturbance on bird communities, aside from those caused by the accompanying modification of vegetation structure (Shahabuddin and Kumar 2006). However, like Francl and Schnell (2002) and Zhang et al. (2013), we found that the difference in bird communities between abandoned and inhabited villages could be ascribed to both changes in human disturbance, and changes in vegetation related to the relocation of local residents. Partial Mantel statistics indicated that, compared to human disturbance, differences in vegetation structure explained more variability in bird species composition.

Many birds increase their tolerance to anthropogenic disturbance in human-dominated environments (Samia et al. 2015). This could be explained by the abundant food discarded by humans, and the birds' long period of adapting to environmental disturbance. Living with humans would be much more beneficial for disturbance-tolerant bird species in winter, when there is a serious shortage of food in the wild (Shochat 2004). Most bird species recorded in this study are widely distributed in the agricultural landscape, and are well adapted to human disturbance (Zheng 2011). There was no species specifically associated with inhabited villages either in summer or winter. In contrast, there were three species in summer and eight in winter that were specific to abandoned villages, which had a much lower level of disturbance. Statistical analyses indicated that most of the bird species responded positively to habitat changes in abandoned villages. Farmland birds are likely to be attracted to habitats with reduced human disturbance and recovered vegetation, even though they have adapted well to the disturbed agricultural environment (Francl and Schnell 2002, Herzon et al. 2008). As an exception, the density of P. montanus was much higher in inhabited villages. This was especially true in winter, when the density of $P$. montanus in inhabited villages was nearly 10 times greater than in abandoned villages.

Habitats for biodiversity in agricultural landscapes undergo more rapid changes than those in nonagricultural regions because of the coexistence with intensive human use of the landscape (Butler et al. 2007, Frenzel et al. 2016). The overlapping underground coal mining in agricultural landscapes often exacerbates humaninduced environmental changes, and thus negatively impacts regional biodiversity (Dong et al. 2015, Lewin et al. 2015). 
Although we found vegetation recovery and thus positive effects on farmland bird assemblages in abandoned villages, our results should be viewed with caution, because of the following two reasons. First, because of the abundant rainfall and high groundwater tables (less than $5 \mathrm{~m}$ below sea level), a large area of subsiding lands in the North China Plain has changed into collapsed ponds, reservoirs, and even small lakes (Hu et al. 2014, Xiao et al. 2017). The land subsidence is still continuing at a high speed (Xie et al. 2013). The recovered terrestrial vegetation and farmland bird assemblages in abandoned villages are very likely to be replaced by flora and fauna communities specific to wetlands in the near future, following the transition from terrestrial ecosystems into subsidence wetlands. Second, we only studied the effect of removal of human disturbance on bird communities in rural settlements at a local scale. Investigations should be carried out to explore how bird communities respond to environmental changes associated with the continuous and extensive underground coal mining at the landscape scale. This is an urgent task given large-scale effects of coal mining on the environment in the agricultural landscape, and the lack of knowledge on farmland biodiversity in China (Liu et al. 2013, Hu et al. 2014).

Despite the fact that we had limited statistical power due to small number of line transects, our study revealed significant responses of farmland birds to habitat changes induced by human relocations in subsiding villages in the Huaibei coal mining area in China. We have provided a small-scale but important case study, adding to our knowledge of farmland bird communities in agricultural landscapes in China, and of impacts of habitat changes associated with underground coal mining. To understand farmland biodiversity and influencing factors in a more general sense, further investigations at broader scales should be launched immediately. Our results may focus attention on the status of biodiversity in agricultural landscapes, provide key information, and help conceive management and conservation plans.

Responses to this article can be read online at: http://www.ace-eco.org/issues/responses.php/1164

\section{Acknowledgments:}

The work was supported by the National Natural Sciences Foundation of China (31770571 and 31301897) and Natural Sciences Foundation of Education Department of Anhui Province (KJ2013A023).

\section{LITERATURE CITED}

Ahnström, J., A. Berg, and H. Söderlund. 2008. Birds on farmsteads - effects of landscape and farming characteristics. Ornis Fennica 85:98-108.

Butler, S., J. Vickery, and K. Norris. 2007. Farmland biodiversity and the footprint of agriculture. Science 315:381-384. http://dx. doi.org/10.1126/science. 1136607

De Caceres, M., and F. Jansen. 2016. indicspecies: Relationship between species and groups of sites. $\mathrm{R}$ package version 1.7.6. [online] URL: https://cran.r-project.org/web/packages/indicspecies/
De Cáceres, M., and P. Legendre. 2009. Associations between species and groups of sites: indices and statistical inference. Ecology 90:3566-3574. http://dx.doi.org/10.1890/08-1823.1

Dong, S., S. Samsonov, H. Yin, S. Yao, and C. Xu. 2015. Spatiotemporal analysis of ground subsidence due to underground coal mining in Huainan coalfield, China. Environmental Earth Sciences 73:5523-5534. http://dx.doi.org/10.1007/s12665-014-3806-4

Fischer, C., A. Flohre, L. W. Clement, P. Batáry, W. W. Weisser, T. Tscharntke, and C. Thies. 2011. Mixed effects of landscape structure and farming practice on bird diversity. Agriculture, Ecosystems \& Environment 141:119-125. http://dx.doi.org/10.1016/ j.agee.2011.02.021

Francl, K. E., and G. D. Schnell. 2002. Relationships of human disturbance, bird communities, and plant communities along the land-water interface of a large reservoir. Environmental Monitoring and Assessment 73:67-93. http://dx.doi.org/10.1023/ A:1012615314061

Frenzel, M., J. Everaars, and O. Schweiger. 2016. Bird communities in agricultural landscapes: What are the current drivers of temporal trends? Ecological Indicators 65:113-121. http://dx.doi.org/10.1016/j.ecolind.2015.11.020

Gaüzère, P., F. Jiguet, and V. Devictor. 2015. Rapid adjustment of bird community compositions to local climatic variations and its functional consequences. Global Change Biology 21:3367-3378. http://dx.doi.org/10.1111/gcb.12917

Gregory, R. D., D. W. Gibbons, and P. F. Donald. 2004. Bird census and survey techniques. Pages 17-56 in W. J. Sutherland, I. Newton, and R. Green, editors. Bird ecology and conservation: a handbook of techniques. Oxford University Press, New York, New York, USA. http://dx.doi.org/10.1093/acprof:oso/9780198520863.003.0002

Herzon, I., A. Auninš, J. Elts, and Z. Preikša. 2008. Intensity of agricultural land-use and farmland birds in the Baltic States. Agriculture, Ecosystems \& Environment 125:93-100. http://dx.doi. org/10.1016/j.agee.2007.11.008

Hiron, M., Å. Berg, S. Eggers, and T. Pärt. 2013. Are farmsteads over-looked biodiversity hotspots in intensive agricultural ecosystems? Biological Conservation 159:332-342. http://dx.doi. org/10.1016/j.biocon.2012.11.018

Hockin, D., M. Ounsted, M. Gorman, D. Hill, V. Keller, and M. A. Barker. 1992. Examination of the effects of disturbance on birds with reference to its importance in ecological assessments. Journal of Environmental Management 36:253-286. http://dx.doi. org/10.1016/S0301-4797(08)80002-3

Hu, Z., G. Yang, W. Xiao, J. Li, Y. Yang, and Y. Yu. 2014. Farmland damage and its impact on the overlapped areas of cropland and coal resources in the eastern plains of China. Resources, Conservation and Recycling 86:1-8. http://dx.doi. org/10.1016/j.resconrec.2014.01.002

Kirk, D. A., D. A. Welsh, J. A. Baker, I. D. Thompson, and M. Csizy. 2012. Avian assemblages differ between old-growth and mature white pine forests of Ontario, Canada: a role for supercanopy trees? Avian Conservation and Ecology 7(1):4. http:// dx.doi.org/10.5751/ACE-00503-070104 
Kong, X. 2014. China must protect high-quality arable land. Nature 506:7. http://dx.doi.org/10.1038/506007a

Krebs, C. A. 1999. Ecological methodology. Second edition. Addison-Wesley Longman, Menlo Park, California, USA.

Lewin, I., A. Spyra, M. Krodkiewska, and M. Strzelec. 2015. The importance of the mining subsidence reservoirs located along the trans-regional highway in the conservation of the biodiversity of freshwater molluscs in industrial areas (Upper Silesia, Poland). Water, Air, \& Soil Pollution 226:189. http://dx.doi.org/10.1007/ s11270-015-2445-Z

Liu, D., Y. Yao, D. Tang, S. Tang, Y. Che, and W. Huang. 2009. Coal reservoir characteristics and coalbed methane resource assessment in Huainan and Huaibei coalfields, southern North China. International Journal of Coal Geology 79:97-112. http:// dx.doi.org/10.1016/j.coal.2009.05.001

Liu, Y., M. Duan, and Z. Yu. 2013. Agricultural landscapes and biodiversity in China. Agriculture, Ecosystems \& Environment 166:46-54. http://dx.doi.org/10.1016/j.agee.2011.05.009

MacArthur, R. H., and J. W. MacArthur. 1961. On bird species diversity. Ecology 42:594-598. http://dx.doi.org/10.2307/1932254

McCune, B., and J. B. Grace. 2002. Analysis of ecological communities. MjM Software Design, Oregon, USA.

Murphy, G. E. P., and T. N. Romanuk. 2014. A meta-analysis of declines in local species richness from human disturbances. Ecology and Evolution 4:91-103. http://dx.doi.org/10.1002/ ece3.909

Oksanen, J., F. G. Blanchet, M. Friendly, R. Kindt, P. Legendre, D. McGlinn, P. R. Minchin, R. B. O'Hara, G. L. Simpson, P. Solymos, M. H. Stevens, E. Szoecs, and H. Wagner. 2017. vegan: Community ecology package. R Package version. 2.4-6. [online] URL: https://cran.r-project.org/web/packages/vegan/

Padoa-Schioppa, E., M. Baietto, R. Massa, and L. Bottoni. 2006. Bird communities as bioindicators: the focal species concept in agricultural landscapes. Ecological Indicators 6:83-93. http://dx. doi.org/10.1016/j.ecolind.2005.08.006

Pielou, E. C. 1966. The measurement of diversity in different types of biological collections. Journal of Theoretical Biology 13:131-144. http://dx.doi.org/10.1016/0022-5193(66)90013-0

R Development Core Team. 2017. R: a language and environment for statistical computing. R Foundation for Statistical Computing, Vienna. [online] URL: https://www.r-project.org/

Rosin, Z. M., P. Skórka, T. Pärt, M. Żmihorski, A. Ekner-Grzyb, Z. Kwieciński, and P. Tryjanowski. 2016. Villages and their old farmsteads are hot spots of bird diversity in agricultural landscapes. Journal of Applied Ecology 53:1363-1372. http://dx. doi.org/10.1111/1365-2664.12715

Samia, D. S., S. Nakagawa, F. Nomura, T. F. Rangel, and D. T. Blumstein. 2015. Increased tolerance to humans among disturbed wildlife. Nature Communications 6:8877. http://dx.doi.org/10.1038/ ncomms 9877

Schütz, C., and C. H. Schulze. 2015. Functional diversity of urban bird communities: effects of landscape composition, green space area and vegetation cover. Ecology and Evolution 5:5230-5239. http://dx.doi.org/10.1002/ece3.1778
Shahabuddin, G., and R. Kumar. 2006. Influence of anthropogenic disturbance on bird communities in a tropical dry forest: role of vegetation structure. Animal Conservation 9:404-413. http://dx.doi.org/10.1111/j.1469-1795.2006.00051.x

Shannon, C. E., and W. Weaver. 1949. The mathematical theory of communication. University of Illinois Press, Urbana, Illinois, USA.

Shochat, E. 2004. Credit or debit? Resource input changes population dynamics of city-slicker birds. Oikos 106:622-626. http://dx.doi.org/10.1111/j.0030-1299.2004.13159.x

Skowno, A. L., and W. J. Bond. 2003. Bird community composition in an actively managed savanna reserve, importance of vegetation structure and vegetation composition. Biodiversity and Conservation 12:2279-2294. http://dx.doi.org/10.1023/ A: 1024545531463

Strohbach, M. W., M. L. Kohler, J. Dauber, and S. Klimek. 2015. High nature value farming: from indication to conservation. Ecological Indicators 57:557-563. http://dx.doi.org/10.1016/j. ecolind.2015.05.021

Thiollay, J.-M. 2006. Large bird declines with increasing human pressure in savanna woodlands (Burkina Faso). Biodiversity and Conservation 15:2085-2108. http://dx.doi.org/10.1007/s10531-004-6684-3

Watson, J. E. M., R. J. Whittaker, and D. Freudenberger. 2005. Bird community responses to habitat fragmentation: how consistent are they across landscapes? Journal of Biogeography 32:1353-1370. http://dx.doi.org/10.1111/j.1365-2699.2005.01256. $\mathrm{x}$

Xiao, W., Z. Wang, R. Zhang, and S. Li. 2017. The 'golden ten years': underground coal mining and its impacts on land use and subsequent social problems: a case study on the Jining city region, China. International Journal of Mining and Mineral Engineering 8:19-34. http://dx.doi.org/10.1504/IJMME.2017.082681

Xie, K., Y. Zhang, Q. Yi, and J. Yan. 2013. Optimal resource utilization and ecological restoration of aquatic zones in the coal mining subsidence areas of the Huaibei Plain in Anhui Province, China. Desalination and Water Treatment 51:4019-4027. http:// dx.doi.org/10.1080/19443994.2013.781096

Xu, W., Y. Xiao, J. Zhang, W. Yang, L. Zhang, V. Hull, Z. Wang, H. Zheng, J. Liu, S. Polasky, et al. 2017. Strengthening protected areas for biodiversity and ecosystem services in China. Proceedings of the National Academy of Sciences 114:1601-1606. http://dx.doi.org/10.1073/pnas.1620503114

Zhang, J., W. D. Kissling, and F. He. 2013. Local forest structure, climate and human disturbance determine regional distribution of boreal bird species richness in Alberta, Canada. Journal of Biogeography 40:1131-1142. http://dx.doi.org/10.1111/jbi.12063

Zhang, L., Z. Luo, D. Mallon, C. Li, and Z. Jiang. 2017 b. Biodiversity conservation status in China's growing protected areas. Biological Conservation 210(Part B):89-100. http://dx.doi. org/10.1016/j.biocon.2016.05.005

Zhang, W., J. Shi, H. Huang, and T. Liu. 2017a. The impact of disturbance from photographers on the Blue-crowned Laughingthrush (Garrulax courtoisi). Avian Conservation and Ecology 12(1):15. http://dx.doi.org/10.5751/ACE-01007-120115 
Zheng, G. 2011. A checklist on the classification and distribution of the birds of China. Second edition. China Science Publishing \& Media Ltd., Beijing, China.

Zlonis, E. J., H. G. Panci, J. D. Bednar, M. Hamady, and G. J. Niemi. 2017. Habitats and landscapes associated with bird species in a lowland conifer-dominated ecosystem. Avian Conservation and Ecology 12(1):7. http://dx.doi.org/10.5751/ACE-00954-120107 
Appendix 1. Bird species recorded in rural settlements located in the Huaibei coal mining area of China. Bird abundance was the total number of individuals (over the five surveys) recorded in abandoned or inhabited villages in summer or winter. $T$-test was used to compare the abundance of each bird species between two village types and significant difference was denoted by * $(\mathrm{P}<0.05)$ or ** $(\mathrm{P}<0.01)$.

\begin{tabular}{|c|c|c|c|c|c|c|c|}
\hline \multirow[b]{2}{*}{ Order } & \multirow[b]{2}{*}{ Family name } & \multirow[b]{2}{*}{ Common name } & \multirow[b]{2}{*}{ Scientific name } & \multicolumn{2}{|c|}{ Abundance in summer } & \multicolumn{2}{|c|}{ Abundance in winter } \\
\hline & & & & $\begin{array}{c}\text { Abandoned } \\
\text { villages }\end{array}$ & $\begin{array}{l}\text { Inhabited } \\
\text { villages }\end{array}$ & $\begin{array}{c}\text { Abandoned } \\
\text { villages }\end{array}$ & $\begin{array}{c}\text { Inhabited } \\
\text { villages }\end{array}$ \\
\hline FALCONIFORMES & Falconidae & Common Kestrel & Falco tinnunculus & 2 & 0 & 3 & 0 \\
\hline GALLIFORMES & Phasianidae & Ring-nacked Pheasant & Phasianus colchicus & 0 & 0 & $18^{*}$ & 0 \\
\hline COLUMBIFORMES & Columbidae & Oriental Turtle-dove & Streptopelia orientalis & $237 * *$ & 55 & $226^{*}$ & 73 \\
\hline COLUMBIFORMES & Columbidae & Eastern Spotted Dove & Spilopelia chinensis & $130 *$ & 36 & $173^{*}$ & 28 \\
\hline BUCEROTIFORMES & Accipitridae & Common Hoopoe & Upupa ерорs & 24 & 1 & 26 & 0 \\
\hline CORACIIFORMES & Alcedinidae & Common Kingfisher & Alcedo atthis & 1 & 0 & 1 & 0 \\
\hline ACCIPITRIFORMES & Accipitridae & Little Egret & Hieraaetus morphnoides & 36 & 0 & 0 & 0 \\
\hline PELECANIFORMES & Ardeidae & Intermediate Egret & Ardea intermedia & 1 & 0 & 0 & 0 \\
\hline PELECANIFORMES & Ardeidae & Chinese Pond-heron & Ardeola bacchus & 2 & 0 & 0 & 0 \\
\hline PELECANIFORMES & Ardeidae & Cattle Egret & Bubulcus ibis & 1 & 0 & 0 & 0 \\
\hline GRUIFORMES & Rallidae & Common Coot & Fulica atra & 0 & 0 & 10 & 1 \\
\hline PICIFORMES & Picidae & Grey-capped Woodpecker & Picoides canicapillus & 11 & 0 & 7 & 4 \\
\hline PICIFORMES & Picidae & Great spotted Woodpecker & Dendropicos spodocephalus & 0 & 0 & 2 & 0 \\
\hline PICIFORMES & Picidae & Grey-headed Woodpecker & Dendrocopos major & 0 & 0 & 4 & 0 \\
\hline PASSERIFORMES & Alaudidae & Oriental Skylark & Alauda gulgula & 2 & 0 & 0 & 0 \\
\hline PASSERIFORMES & Hirundinidae & Barn Swallow & Hirundo rustica & 126 & 139 & 0 & 0 \\
\hline PASSERIFORMES & Hirundinidae & Red-rumped Swallow & Cecropis daurica & 4 & 4 & 0 & 0 \\
\hline PASSERIFORMES & Motacillidae & Olive-backed Pipit & Anthus hodgsoni & 0 & 0 & 14 & 2 \\
\hline
\end{tabular}




\begin{tabular}{|c|c|c|c|c|c|c|c|}
\hline PASSERIFORMES & Motacillidae & Forest Wagtail & Dendronanthus indicus & 0 & 1 & 0 & 0 \\
\hline PASSERIFORMES & Motacillidae & White Wagtail & Motacilla alba & 25 & 7 & 17 & 11 \\
\hline PASSERIFORMES & Pycnonotidae & Light-vented Bulbul & Pycnonotus sinensis & $826 * *$ & 152 & $928 * *$ & 220 \\
\hline PASSERIFORMES & Turdidae & Common Blackbird & Turdus merula & 71 & 42 & 182 & 114 \\
\hline PASSERIFORMES & Turdidae & Dusky Thrush & Turdus eunomus & 0 & 0 & 13 & 6 \\
\hline PASSERIFORMES & Muscicapidae & Daurian Redstart & Phoenicurus auroreus & 10 & 1 & 5 & 3 \\
\hline PASSERIFORMES & Muscicapidae & Orange-flanked Bush-robin & Tarsiger cyanurus & 0 & 0 & 7 & 0 \\
\hline PASSERIFORMES & Campephagidae & Ashy Minivet & Pericrocotus divaricatus & 22 & 0 & 0 & 0 \\
\hline PASSERIFORMES & Sylviidae & Vinous-throated Parrotbill & Sinosuthora webbiana & 26 & 0 & 40 & 0 \\
\hline PASSERIFORMES & Paridae & Yellow-bellied Tit & Pardaliparus venustulus & 0 & 0 & 12 & 0 \\
\hline PASSERIFORMES & Paridae & Great Tit & Parus major & 17 & 8 & $158 *$ & 40 \\
\hline PASSERIFORMES & Aegithalidae & Northern Long-tailed Tit & Aegithalos caudatus & 6 & 0 & $63 *$ & 8 \\
\hline PASSERIFORMES & Laniidae & Brown Shrike & Lanius cristatus & $235 * *$ & 54 & 0 & 0 \\
\hline PASSERIFORMES & Laniidae & Long-tailed Shrike & Lanius schach & $40 *$ & 6 & $35 * *$ & 3 \\
\hline PASSERIFORMES & Corvidae & Asian Azure-winged Magpie & Cyanopica cyanus & 88 & 29 & 65 & 38 \\
\hline PASSERIFORMES & Corvidae & Black-billed Magpie & Pica hudsonia & 25 & 15 & 121 & 13 \\
\hline PASSERIFORMES & Sturnidae & White-cheeked Starling & Spodiopsar cineraceus & 90 & 49 & $1109 *$ & 114 \\
\hline PASSERIFORMES & Passeridae & Eurasian Tree Sparrow & Passer montanus & 255 & $727 * *$ & 120 & $1173^{*}$ \\
\hline PASSERIFORMES & Dicruridae & Black Drongo & Dicrurus macrocercus & $93 *$ & 19 & 0 & 0 \\
\hline PASSERIFORMES & Fringillidae & Brambling & Fringilla montifringilla & 0 & 0 & 59 & 0 \\
\hline PASSERIFORMES & Fringillidae & Grey-capped Greenfinch & Chloris sinica & 0 & 0 & 53 & 0 \\
\hline PASSERIFORMES & Fringillidae & Chinese Grosbeak & Eophona migratoria & 51 & 0 & 64 & 22 \\
\hline PASSERIFORMES & Muscicapidae & Yellow-rumped Flycatcher & Ficedula zanthopygia & 0 & 1 & 0 & 0 \\
\hline PASSERIFORMES & Leiotrichidae & Chinese Hwamei & Garrulax canorus & 2 & 0 & 0 & 0 \\
\hline PASSERIFORMES & Emberizidae & Ochre-rumped Bunting & Emberiza yessoensis & 0 & 0 & 3 & 0 \\
\hline
\end{tabular}




\begin{tabular}{lllllll}
\hline PASSERIFORMES & Emberizidae & Yellow-throated Bunting & Emberiza elegans & 0 & 0 & $45^{*}$ \\
PASSERIFORMES & Emberizidae & Black-faced Bunting & Emberiza spodocephala & 0 & 0 & 4 \\
PASSERIFORMES & Emberizidae & Meadow Bunting & Emberiza cioides & 0 & 0 & 2 \\
PASSERIFORMES & Emberizidae & Little Bunting & Emberiza pusilla & 0 & 0 & 0 \\
\hline
\end{tabular}

